\title{
An integrated source-fate-effects model for sedimentary metals in Sydney estuary and catchment (Australia)
}

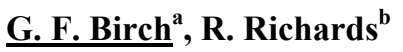 \\ ${ }^{a}$ Environmental Geology Group, School of Geosciences, Sydney University, NSW, 2006, Australia. \\ ${ }^{b}$ Griffith Climate Change Response Program, Griffith Centre for Coastal management, Griffith University, \\ Queensland \\ Email: gavin.birch@sydney.edu.au
}

\begin{abstract}
Sediments in Sydney estuary (Australia) and soils of the catchment are highly enriched in copper $(\mathrm{Cu})$, lead $(\mathrm{Pb})$ and zinc $(\mathrm{Zn})$ and these metals are accumulating in tissue of estuarine fauna. To reduce contamination levels, especially in the tissue of bivalve filter-feeders, it is necessary to understand the processes linking source, fate and effects of metals in these environments. It was the aim of the current work to identify key mechanisms controlling bioaccumulation in shellfish inhabiting this estuary by combining the results of existing individual models and monitoring data (oyster soft-tissue concentrations) describing various parts of this system into a single source-fate-effects model. Of the existing models, an atmospheric model (TAPM) showed that vehicle emissions were the major contributor of metals to catchment soils while stormwater modelling indicated that the average annual discharge from Sydney estuary catchment ranged 215,300 - 372,000 ML with associated loadings of 60,400, 30.5, 49.0 and 89.2 tonnes for total suspended solids (TSS), $\mathrm{Cu}, \mathrm{Pb}$ and $\mathrm{Zn}$, respectively. A verified hydrodynamic model investigated estuarine response to catchment rainfall and showed that fresh-water plumes generated during high-rainfall events broke down within the estuary and that minimal $(<1 \%)$ associated contaminants exited the estuary to the ocean, whereas TSS and pollutants delivered during low-rainfall were deposited close to discharge points and were trapped within the estuary. Oyster (Saccostrea glomerata) tissue was highly enriched in these metals, however there was no significant relationship with bottom sediment metal concentrations.
\end{abstract}

The integrated model used here comprised a process-based framework describing the water and sediment balance coupled to a chemical $(\mathrm{Cu})$ speciation model and an oyster bioaccumulation model. This integrated model is not spatially explicit on the horizontal plan but consists of two vertical components (aqueous layer and sediment). Early results of the source-fate-effects modelling indicate that the increase in dissolved and particulate organic ligands associated with a stormwater event entering the system appears unable to compensate for the concomitant increase in aqueous $\mathrm{Cu}$ and that the excess may be associated with dissolved inorganic ligands after the organic complexation sites have been exhausted. Modelling provides evidence that mechanisms driving pollution in the estuary are sensitive to catchment loading rates, which may result in highly variable soft-tissue $\mathrm{Cu}$ concentration in oysters.

Keywords: Metals, atmospheric deposition, fluvial loading, Sydney estuary, hydrodynamic, vehicles 
Birch and Richards, An integrated source-fate-effects model for sedimentary metals in Sydney estuary and catchment (Australia)

\section{INTRODUCTION}

Research into metal contamination in Sydney estuary (Figure 1) and catchment (Australia) has been underway for almost 25 years. This work has resulted in a vast amount of data on water and sediment quality in the catchment and estuary, as well as on metal accumulation in flora and fauna in the system. Sediments in Sydney estuary are contaminated by a wide range of chemicals sourced mainly from stormwater (Birch and Taylor, 1999, 2000). Metals $(\mathrm{Cu}, \mathrm{Pb}$ and $\mathrm{Zn})$ are of particular concern as they are bioaccumulating in tissue of local filter-feeding mussels and oysters, as well as in prawns and fish. Consequently, there is a demand to reduce metal levels throughout the catchment-estuary system, which requires a better understanding of the processes and linkages between source, fate and effects of these metals in these environments.

Environmental models of the system have also been constructed for metals over this period, including an atmospheric deposition model for vehicular emissions (Lawrence, 2006), loading models (Birch and Rochford, 2010) and a hydrodynamic model (Lee et al., 2011; Lee and Birch, 2012). The objectives of the present work are to briefly describe the models already constructed and provide major outcomes from these studies. Results from previous investigations will be synthesised into an integrated metal source-fate-effects model with the objective of better understanding how the different contaminant pathways in the estuary contribute to the temporal bioavailability and uptake of $\mathrm{Cu}$ in resident oysters.

\section{THE MODELS}

\subsection{The atmospheric deposition model}

A detailed emissions inventory of vehicular sources was compiled using traffic volumes and standard emission factors (Lawrence, 2006). PM10 emissions were estimated using the mix of vehicle types, fuel types, speed of traffic and vehicle kilometres travelled (VKT). The Atmospheric Pollution Model (TAPM) was employed to map the dispersal of PM10 emissions in Sydney catchment using a network of 20,700 individual road sections, including terrain and topographic models. Meteorological data were used to drive dispersion of air pollutants in the atmosphere.

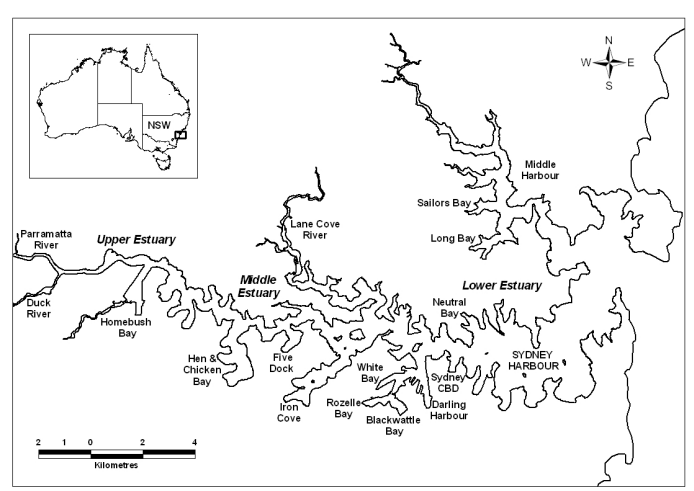

Figure 1. Sydney estuary, Australia (site map).

\subsection{Hydrologic Models}

Two loading models were used to estimate water, TSS and metal discharge to Sydney estuary. Stormwater collected from channels entering Sydney estuary were analysed for dissolved $(0.45 \mu \mathrm{m})(\mathrm{n}=686)$ and particulate $(\mathrm{n}=790)$ phase metals and modelled using The Model for Urban Stormwater Improvement Conceptualisation (MUSIC) software (Birch and Rochford, 2010). The second method to calculate annualised catchment loading was The Simple Empirical Model (NSW EPA. 2001), the general formula for which is:

$\mathrm{L}=\mathrm{P} \times \mathrm{A} \times \mathrm{C} \times \mathrm{RC} \times \mathrm{EMC}$

Where $\mathrm{L}$ is loading $\left(\mathrm{kg} \mathrm{y}^{-1}\right)$; $\mathrm{P}$ is rainfall intensity $\left.(\mathrm{mm} \mathrm{y})^{-1}\right)$; $\mathrm{A}$ is catchment area $\left(\mathrm{km}^{2}\right)$; $\mathrm{RC}$ is Runoff coefficient and EMC is event mean concentration $\left(\mathrm{mg} \mathrm{l}^{-1}\right)$.

\subsection{The Hydrodynamic Model}

An Environmental Fluid Dynamics Computer Code (EFDC) three-dimensional hydrodynamic computational model was used to replicate flow patterns within Sydney estuary (Lee et al., 2011). RGFGrid software (Delft Hydraulics) was used to construct the horizontal grid comprising 12309 cells with an average cell size of $70 \mathrm{~m} \times 62 \mathrm{~m}$ and up to 15 vertical sigma layers. Model verification was made by successfully comparing 
Birch and Richards, An integrated source-fate-effects model for sedimentary metals in Sydney estuary and catchment (Australia)

measured and simulated results for water level, discharge and velocity.

\subsection{The integrated hydrologic and hydrodynamic model}

The EFDC hydrodynamic model was integrated with the hydrologic model (Lee and Birch, 2012), which allowed the response of the estuary to high-precipitation events to be determined.

\subsection{The source-fate-effects model}

A conceptualisation of the source-fate-effects model, which is used as the framework for integrating the existing models and oyster data, is presented in Figure 2. This figure shows the cycling of sediment and metals within the Sydney estuary. The estuary is horizontally-averaged (single box model) whilst the vertical component consists of two compartments (aqueous layer and surface sediment). Sediment and $\mathrm{Cu}$ enter the estuary via catchment loading (stormwater) and via deposition from the atmosphere (wet and dry). The effects part of the model tracks the bioaccumulation of $\mathrm{Cu}$ in a single oyster, standardised to $1 \mathrm{~g}$ soft-tissue weight (dry weight basis).

State variables tracked dynamically within the integrated model are the concentrations of particulate inorganic matter $\left(\mathrm{PIM}_{\mathrm{TOT}}\right)$, particulate organic matter $\left(\mathrm{POM}_{\mathrm{TOT}}\right)$, total $\mathrm{Cu}\left(\mathrm{Cu}_{\mathrm{TOT}}\right)$, dissolved $\mathrm{C}\left(\mathrm{C}_{\mathrm{TOT}}\right.$ as carbonate), dissolved $\mathrm{S}$ ( $\mathrm{S}_{\mathrm{TOT}}$ as sulphate), dissolved organic matter $\left(\mathrm{DOM}_{\mathrm{TOT}}\right)$ and soft-tissue metal in the oyster along with $\mathrm{pH}$ (as proton activity, $a \mathrm{H}$ ). $\mathrm{Cu}$ concentrations in the water column (particulate and dissolved) are used to calculate soft-tissue concentrations in the oyster $\left(\mathrm{Cu}_{\mathrm{OYS}}\right)$ using first-order biokinetic equations (Richards et al., 2010). Finally, there is a state variable that tracks the underlying sediment, which is coupled to the suspended sediment and metals in the overlying water column through processes of settlement and resuspension.

The process-based component of the source-fate-effects model (Figure 2) is directly coupled to a $\mathrm{Cu}$ speciation sub-model (refer Richards et al., 2010 for complexation equations involved). At each time step, the current values of the state variables for the aqueous layer are sent to the chemical speciation model. Here they are used to calculate the concentrations of $\mathrm{Cu}$ distributed between the particulate and dissolved phases, and between the inorganic and organic phases. The $\mathrm{Cu}$ species in the water column are calculated using the method of principal components (van der Lee, 1998; Richards et al., 2010). In this approach, a series of principal components (PIM [as HFO_OH], POM, DOM, $\mathrm{SO}_{4}^{-2}, \mathrm{CO}_{3}^{-2}, \mathrm{H}^{+}$and $\mathrm{Cu}^{+2}$ ) are used to simultaneously calculate the concentrations of a suite of secondary species (e.g. $\mathrm{CuOH}^{+}, \mathrm{HFO} \mathrm{OCu}^{+}$, $\mathrm{CuCO}_{3}$ ) using a modified version of the Newton-Rhapson method. Speciation calculations are conducted iteratively until the difference between the actual total concentrations and estimated total concentrations (calculated from the principal components) is minimised.

The sequence of calculations uses the following procedure. For the first time step $\left(\mathrm{t}_{0}\right)$, initial conditions specified in the model set-up initiate the modelling process and are used to solve the state variables of the process-based part of the model. This enables the current distribution of metals to be used in calculating changes to the total $\mathrm{Cu}$ concentration in the system (e.g. $\mathrm{Cu}$ adsorbed to the particulates can be

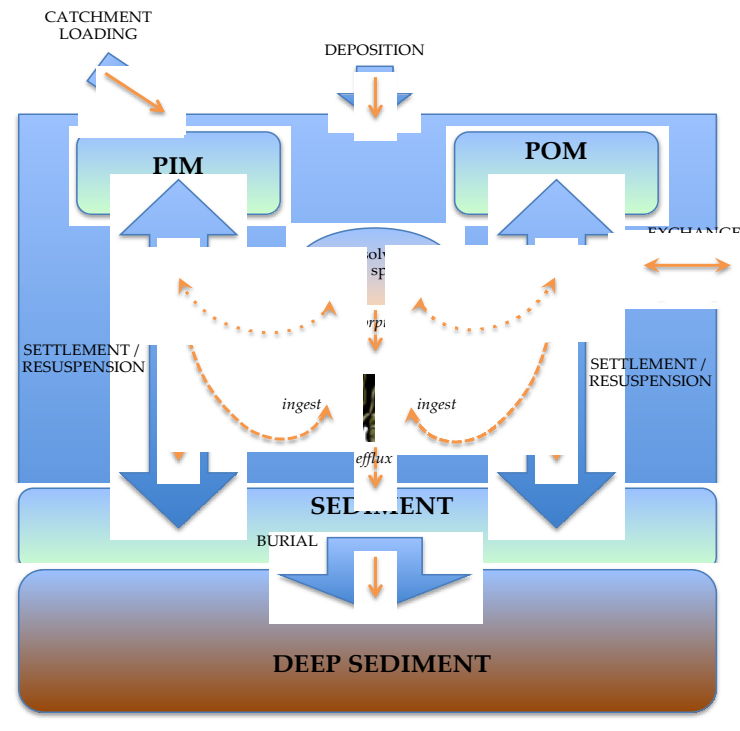

Figure 2. Conceptualisation of the single-box source-fate-effects model. Solid arrows indicate transfer pathways, dotted orange lines represent metal speciation and dashed orange lines represent oyster input/output pathways for $\mathrm{Cu}$. 
Birch and Richards, An integrated source-fate-effects model for sedimentary metals in Sydney estuary and catchment (Australia)

added or removed from the system through oceanic exchange). The state variable solutions are then sent to the $\mathrm{Cu}$ speciation model where they are used to update the distribution of $\mathrm{Cu}$ species between the different phases (dissolved - particulate; organic - inorganic). These speciation calculations are then used to provide the initial conditions for the following timestep.

\section{State equations and parameters}

The general forms for the aqueous $\left(\mathrm{X}_{\mathrm{j}}=\mathrm{POM}_{\mathrm{TOT}}, \mathrm{PIM}_{\mathrm{TOT}}, \mathrm{Cu}_{\mathrm{TOT}}, \mathrm{C}_{\mathrm{TOT}}, \mathrm{S}_{\mathrm{TOT}}, \mathrm{DOM}_{\mathrm{TOT}}\right)$ and sediment $\left(\mathrm{X}_{\mathrm{k}}=\right.$ $\mathrm{Cu}_{\mathrm{SED}}, \mathrm{SED}_{\mathrm{ORG}}, \mathrm{SED}_{\text {INORG }}$ ) constituents are shown in [2] and [3] respectively. The concentration of each aqueous species is dependent upon the contributions of atmospheric deposition $\left(\mathrm{X}_{\mathrm{DEPOT}, \mathrm{j}}\right)$, stormwater loading $\left(X_{S W, j}\right)$, oceanic exchange $(\rho)$, settling to the sediment $(S R)$ and resuspension rate $(R R)$ of the sediment. The mass of each sediment species is dependent only on settling from the water column and the resuspension from the sediment. The soft-tissue $\mathrm{Cu}$ concentration in the oyster $\left(\mathrm{Cu}_{\mathrm{OYS}}\right)$ is calculated using a biokinetic approach [4], where uptake $\left(\mathrm{k}_{\mathrm{u}}\right)$ and efflux $\left(\mathrm{k}_{\mathrm{e}}\right)$ rates control the uptake and depuration of $\mathrm{Cu}$ in the oyster, respectively.

The calibrated parameters for the dynamic component of the source-fate-effects model are presented in Table 1. Other parameters, including the estuary dimensions, atmospheric deposition rates, stormwater loading, oyster biokinetic parameters and $\mathrm{Cu}$ speciation stability constants are the same as used elsewhere (Birch \& Taylor 2004; Lawrence, 2006; Birch \& Rochford, 2010; Richards et al., 2010). The annual atmospheric loadings to the estuary are obtained from the atmospheric deposition model and used to calculate constant daily loading rates for the pollutants (sediment and $\mathrm{Cu}$ ). The catchment loading model was used to derive event-based concentrations for $\mathrm{Cu}$ and total suspended sediment (TSS) with the concentrations of POM and PIM estimated from TSS.

$$
\begin{aligned}
& \frac{d\left[X_{j}\right]}{d t}=\left(\frac{R R \times X_{\text {sed,j }}}{V o l}\right)+\left(\frac{X_{\text {depot }, j}+Q \times X_{s w, j}}{V o l}\right)-\left(\frac{1}{\text { depth }} \times S R \times X_{j}\right)+\rho \times\left(X_{o, j}-X_{j}\right) \\
& \frac{d\left[X_{k}\right]}{d t}=R R \times X_{s e d, k}-S R \times X_{k} \times V o l \times \frac{1}{\text { depth }} \\
& \frac{d\left[O Y S_{C u}\right]}{d t}=\left(k_{u} \times C u_{T}\right)-\left(k_{e} \times O Y S_{C u}\right)
\end{aligned}
$$

\section{Calibration}

The source-fate-effects model, run using median values for stormwater, is calibrated by adjusting resuspension rate $\left(\mathrm{d}^{-1}\right)$ and the oceanic mixing coefficient $\left(\mathrm{d}^{-1}\right)$ to simultaneously achieve an annual increase in sediment depth of $1.75 \mathrm{~cm}$ and recovery period to quiescent conditions (total suspended sediment) after a stormwater event of 28 days (Lee et al., 2011). The 'stormwater event' used in the model is a pulse event starting on days 50 and 415 of the simulation run, each with a duration of three days. The mean annual stormwater flow is equally distributed over these three days (i.e. average flow over these days).

\section{Model setting}

The source-fate-effects model was coded within R (Ihaka and Gentleman 1996), an open-source software environment for statistical computing and graphics. Differential equation calculations used in the kinetic submodel were solved using the deSolve package (Soetaert et al., 2010). The model was run for a three-year period (first 12 months used as 'burn-in') at a time step of 1 day.

\section{Monte Carlo simulations}

Monte Carlo simulations were carried out using the calibrated model to investigate the effects of variability in the stormwater concentrations of TSS $\left(\mathrm{TSS}_{\mathrm{SW}}\right)$ and $\mathrm{Cu}\left(\mathrm{Cu}_{\mathrm{SW}}\right)$ and its impact on performance. Both parameters were sampled from log-normal distributions (assigned per Monte Carlo run) derived from the event mean concentrations (EMCs) observed for TSS and $\mathrm{Cu}$. For TSS $\mathrm{SW}$, the concentrations associated with lower and higher EMCs were assumed to represent the 5th and 95th percentile values of a log-normal distribution. For $\mathrm{Cu}_{\mathrm{sw}}$, the concentrations associated with lower and mean (no higher value available) EMCs 
Birch and Richards, An integrated source-fate-effects model for sedimentary metals in Sydney estuary and catchment (Australia)

were assumed to represent the 5th and 50th percentile values. See Richards et al., 2010 regarding using this method for estimating log-normal probability density functions. For the Monte Carlo simulation, the model was run 250 times for 730 days (two years) at daily time steps.

\section{RESULTS}

\subsection{Atmospheric Deposition}

Particulates from the Sydney road network are dispersed widely with a close correlation to road density. All areas of the catchment were impacted to some degree by metal deposition from vehicles and distribution patterns for $\mathrm{Cu}, \mathrm{Pb}$ and $\mathrm{Zn}$ are similar. Metal concentrations were higher in the southern catchment centred

Table 1. Calibrated parameters used in the integrated model

\begin{tabular}{|l|c|}
\hline \multicolumn{1}{|c|}{ Parameter } & Value \\
\hline Particulate resuspension rate & $5.85 \times 10^{-4} \mathrm{~d}^{-1}$ \\
\hline Oceanic exchange coefficient & $0.24 \mathrm{~d}^{-1}$ \\
\hline Monte Carlo setting & $\log -\mathrm{N}(11.99,4.41)$ \\
\hline Monte Carlo setting & $\log -\mathrm{N}(4.41,0.79)$ \\
\hline
\end{tabular}

on high traffic-volume arterial roads. In 2005 total deposition of $\mathrm{Cu}, \mathrm{Pb}$ and $\mathrm{Zn}$ was $221 \mathrm{~kg} \mathrm{yr}^{-1}, 2768$ $\mathrm{kg} \mathrm{yr}^{-1}$ and $1101 \mathrm{~kg} \mathrm{yr}^{-1}$ and deposition of $\mathrm{Cu}$ and $\mathrm{Zn}$ was increasing due to increased traffic volume, whereas deposition of $\mathrm{Pb}$ was decreasing consistent with the reduction in $\mathrm{Pb}$ content of fuel. Wet and dry deposition followed similar trends and dry deposition represented approximately 78\%, 71\%

and $68 \%$ of total deposition for $\mathrm{Cu}, \mathrm{Pb}$ and $\mathrm{Zn}$, respectively.

\subsection{Catchment Loading}

Annual rainfall was extremely erratic consisting of long dry periods (65\% of the time) punctuated by infrequent short high-precipitation ( $>50 \mathrm{~mm} /$ day) events ( $1 \%$ of the time) (Lee and Birch, 2012). For the simulation period 1990 to 2006, average annual discharge of stormwater from the Sydney estuary catchment was $215,300 \mathrm{ML}$ and the proportion of stormwater discharge attributed to daily precipitation rates for low-, medium-, and high-precipitation was approximately 10\%, 60\% and 30\%, respectively (Birch and Rochford, 2010). Annual average loadings in tonnes of metals were 3.2, 3.6 and $17.7 \mathrm{for} \mathrm{Cu}, \mathrm{Pb}$ and $\mathrm{Zn}$, respectively. In a separate study using published EMCs for median values estimated annual discharge at $372,032 \mathrm{ML}$ with 60,400 tonnes of TSS and 30.4, 49.0 and 89.1 tonnes of $\mathrm{Cu}, \mathrm{Pb}$ and $\mathrm{Zn}$, respectively. Modelling of five highprecipitation events in $2007 / 08$ gave a total of 6,718 tonnes TSS, i. e. between $10 \%$ and $33 \%$ of annual loading depending on whether the lower or median EMC was used for TSS (Lee and Birch, 2012).

\subsection{Estuarine transport}

During high-precipitation events, rainwater is rapidly transported to the estuary from a small, highlyurbanised, impervious catchment with an efficient stormwater drainage system. A fresh-water plume developed along the main estuary channel during these short, high-runoff events resulting in stratification of the water column. Stratification broke down within a few days of rainfall ceasing and generally the plume did not escape the estuary to the ocean, instead it mixed with lower saline water and was mainly retained in the estuary (Lee and Birch, 2012).

\subsection{Metal in oysters tissue}

Mean concentrations (dw) of $\mathrm{Cu}, \mathrm{Pb}, \mathrm{Zn}$ was $1418 \mu \mathrm{g} \mathrm{g}^{-1}\left(174-4605 \mu \mathrm{g} \mathrm{g}^{-1}\right), 8.9 \mu \mathrm{g} \mathrm{g}^{-1}\left(1.3-18 \mu \mathrm{g} \mathrm{g}^{-1}\right)$ and $6518 \mu \mathrm{g} \mathrm{g}^{-1}\left(2157-13552 \mu \mathrm{g} \mathrm{g}^{-1}\right)$, respectively. Oyster tissue metal concentrations were spatially irregular throughout Sydney estuary. Lead concentrations in oyster tissue exhibited the strongest relationships to sediment levels and $\mathrm{Zn}$ tissue concentrations were weakly related with $\mathrm{Zn}$ in TSS, whereas $\mathrm{Cu}$ tissue concentrations were not statistically correlated with any sediment size fraction.

\subsection{Integrated model}

The calibration process for the source-fate-effects model resulted in a resuspension rate of $0.0051 \mathrm{~d}^{-1}$ and an oceanic exchange rate $(\rho)$ of $0.033 \mathrm{~d}^{-1}$. These parameter values were fitted so that (1) the aqueous concentrations of POM and PIM (together representing TSS) recovered to their (within 10\%) pre-event levels 28 days after cessation of the event and (2) the annual net increase in sediment depth was $2 \mathrm{~cm}$. 
Birch and Richards, An integrated source-fate-effects model for sedimentary metals in Sydney estuary and catchment (Australia)

Applying the model, it was observed that during stormwater events the resulting increase in $\mathrm{Cu}$ concentration in the water column tended to also increase the dissolved inorganic fraction, mainly through the formation of $\mathrm{CuCO}_{3}$ whereas after the cessation of the stormwater event, the dissolved inorganic fraction decreased as the total aqueous concentration reduced.

Running the model as Monte Carlo (250 simulations) highlighted that the concentration of TSS and $\mathrm{Cu}$ during and immediately after a stormwater event could vary by an order of magnitude, depending on the concentration of these constituents in the stormwater (Figure 3). This variability manifested quite clearly in the calculations of $\mathrm{Cu}$ bioaccumulation in the oyster, with strong accumulation and depuration shown around the stormwater events (Figure 3).

\section{DISCUSSION}

\subsection{Supply, transport and bioaccumulation of metals}

In the Sydney estuary catchment the relative contribution of vehicles to total emissions was high due to lower contributions from local industry. Metals are widely dispersed in the catchment and approximately $2.3 \%$ of total metal deposition was directly to estuary water surface. Contrary to previous belief, freshwater plumes generated by high-rainfall events did not migrate out of the estuary as a discrete upper water layer (Birch and Taylor, $1999)$, instead the vast majority of TSS (97\%) and associated contaminants were deposited within the estuary. Rainfall during highprecipitation delivered between $10-30 \%$ of the total annual flow, whereas TSS and contaminants transported by low/medium rainfall were trapped close to discharge points.
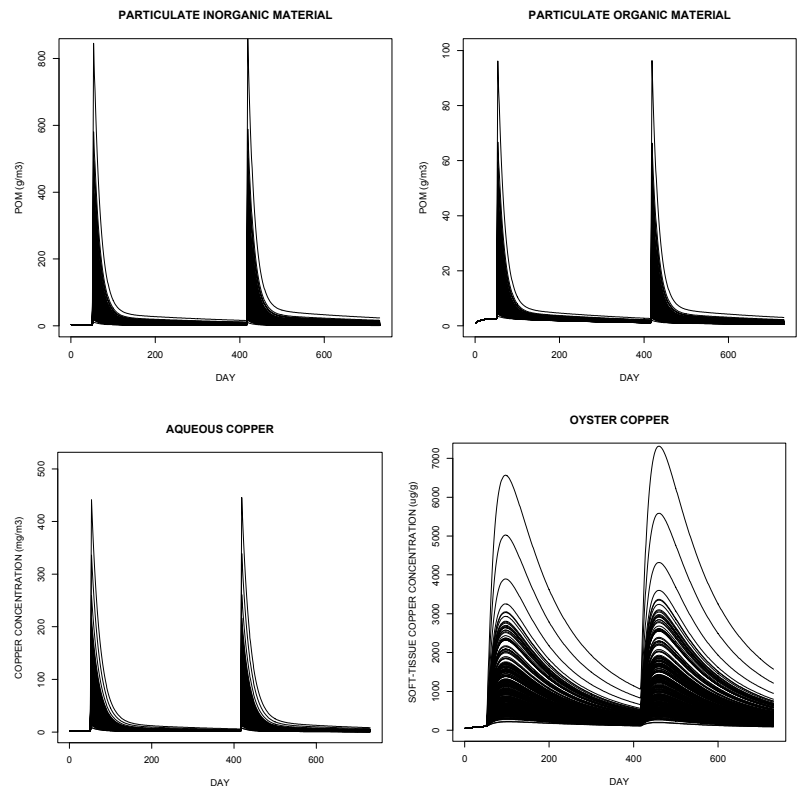

Figure 3. Monte Carlo out put (clockwise from top-left) $\mathrm{PIM}, \mathrm{POM}, \mathrm{Cu}_{\mathrm{T}}$ and oyster-copper concentration.

Thus only $<1 \%$ of the total TSS suppled to the estuary annually escaped to the ocean. Oyster metal tissue concentrations in Sydney estuary study were high compared global levels (Cantillo, 1998). The generally poor correlation between metal concentrations in oyster tissue and various fractions of bottom sediment may be due to a number of factors, including natural (resuspension, stormwater) and anthropogenic (localised contamination) processes and internal regulation (homoestasis) of metals by the animal.

\subsection{Integrated source-fate-effects model}

Finally, we used an integrated source-fate-effects model as a mechanism for coupling the source (catchment, atmosphere), fate (pelagic-benthic coupling; speciation) and response (bioaccumulation) of one of the metals investigated $(\mathrm{Cu})$. The calibrated kinetic component of the integrated model provided estimates of the oceanic mixing coefficient (rho) and resuspension rate that appear realistic. However, these values should be contextualised by the constraints of the model, principally that the model is not spatially explicit in the horizontal plane. This approach, whilst pragmatic as a means of representing a 'first approximation' of the dynamics in the estuary, cannot account for the strongly heterogenous mixing properties that likely characterise this system. Consequences of this approach include numerical dispersion, which entails that the constituents are (in the model) transported through the system far too quickly.

Early investigations indicate that the increase in dissolved and particulate organic ligands associated with a stormwater event (entering the system with the stormwater) appear unable to compensate for the concomitant increase in aqueous $\mathrm{Cu}$ given that the affinity of $\mathrm{Cu}$ for complexation in seawater is (typically) strongest for 
Birch and Richards, An integrated source-fate-effects model for sedimentary metals in Sydney estuary and catchment (Australia)

organic ligands (Stumm and Morgan, 1970). Thus in this case, it appears that the 'slack' is picked up by the dissolved inorganic ligands, particularly by $\mathrm{CO}_{3}^{-2}$, after the organic complexation sites have been exhausted.

Monte Carlo modelling, where the concentration of TSS and $\mathrm{Cu}$ in the stormwater were randomly varied between low and high values, provides evidence that our understanding of the mechanisms driving pollution in the estuary are sensitive to catchment loading rates. This is exemplified by the order of magnitude difference in aqueous concentrations that were observed. The flow-on implications of this variability on environmental fate are that the soft-tissue concentration in oysters could also vary by a large magnitude.

Finally, we acknowledge that this model is exploratory and used as a 'numerical playground' to formulate testable hypotheses. It also provides a starting template for better characterising the estuary through integrative modelling.

\section{REFERENCES}

Apostolatos, C. 2012. The use of the Sydney rock oyster (Saccostrea glomerata) and black mussel (Mytilus galloprovincialis) in determining the role of sediment in metal bioaccumulation in Sydney estuary, Australia. Unpubl. MSc thesis. School of Geosciences, The University of Sydney, Australia.

Birch, G, F., Taylor, S. (1999). Source of heavy metals in sediments of the Port Jackson estuary, Australia. The Science of the Total Environment, 227, 123-138.

Birch, G. F., Taylor, S. E. (2000). The distribution and possible sources of organochlorine residues in sediments of a large urban estuary, Port Jackson, Sydney. Australian Journal of Earth Sciences, 47, 749-756.

Birch, G. F. and Taylor, S. E., 2004. 'Sydney Harbour and Catchment: Contaminant Status of Sydney Harbour Sediments: A Handbook for the Public and Professionals'. Published by the Geological Society of Australia, Environmental, Engineering and Hydrogeology Specialist Group, 101p.

Birch, G.F., and Rochford, L., 2010. Stormwater metal loads to the Sydney estuary (Australia). Environmental Modelling and Assessment, DOI 10.1007/s10661-009-1195-z

Bowie, G.L., Mills, W.B., Porcella, D.B., Campbell, C.L., Pagenkopf, J.R., Rupp, G.L., Johnson, K.M., Chan, P.W.H., Gherini, S.A., Chamberlain, C.E., (1985). Rates, constants, and kinetics formulations in surface water quality modeling. 2nd edn. Athens: Environmental Research Laboratory Office of Research and Development U.S. Environmental Protection Agency.

Cantillo, A.Y., (1998). Comparison of results of Mussel Watch Programs of the United States and France with Worldwide Mussel Watch Studies. Marine Pollution Bulletin 36, 712-717.

Dzombak DA, Morel FMM. (1990). Surface complexation modelling:hydrous ferric oxide. New York: Wiley.

Ihaka, R., Gentleman, R., (1996). R: a language for data analysis and graphics. Journal of Computational and Graphical Statistics 5, 299-314.

Lawrence, M., 2006. Modelling atmospheric deposition of vehicular emissions in an Australian urban environment. Unpubl. BSc Hons thesis. School of Geosciences, The University of Sydney, Australia.

Lee, S. B., Birch, G. F., and Lemckert, C. J., 2011 Field and modelling investigations of fresh-water plume behaviour in response to infrequent high-precipitation events, Sydney Estuary, Australia, Journal of Estuarine, Coastal and Shelf Science, 92, 389-402.

Lee, S., B., Birch., G. F., 2012. Utilising monitoring and modelling of estuarine environments to investigate catchment conditions responsible for stratification events in a typically well-mixed urbanised estuary. Journal of Estuarine and Coastal Shelf Science, 111, 1-6.

MUSIC Development Team. (2005). MUSIC User Manual. Cooperative Research Centre for Catchment Hydrology, Melbourne, Victoria, Australia.

NSW EPA, 2001. Evaluation of the urban stormwater program. Report 2001/65, New South Wales Environmental Protection Agency, Australia.

Richards, R.G., Chaloupka, M., Tomlinson, R., (2010). Towards an integrated ecosystem-based bioaccumulation and metal speciation model. Ecosystems 13, 1303-1318.

Smith, R.H., Martell, A.E., (1974). Critical stability constants Volume 4: Inorganic complexes. New York, Plenum Press.

Soetaert, K., Petzoldt, T., Setzer, R.W., (2010). Solving Differential Equations in R: Package deSolve. Journal of Statistical Software 33(9), 1-25.

Stumm, W., Morgan, J.J., (1970). Aquatic Chemistry - An introduction emphasizing chemical equilibria in natural waters. Wiley-Interscience, London. 